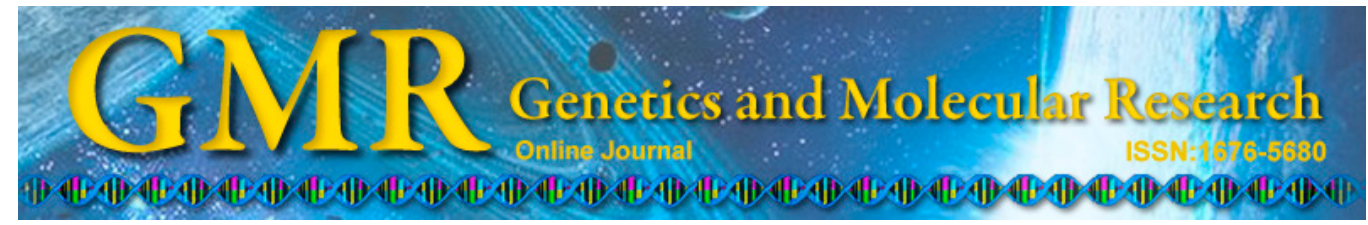

\title{
Karyotype structure of Hypostomus cf. plecostomus (Linnaeus, 1758) from Tapajós River basin, Southern Amazon: occurrence of sex chromosomes $(\mathrm{ZZ} / \mathrm{ZW})$ and their evolutionary implications
}

\author{
L.C. Oliveira ${ }^{1}$, M.O. Ribeiro ${ }^{2}$, E.S. Dutra ${ }^{3}$, C.H. Zawadzki ${ }^{4}$, \\ A.L.B. Portela-Castro ${ }^{5}$ and I.C. Martins-Santos ${ }^{5}$ \\ ${ }^{1}$ Departamento de Ciências Biológicas, Universidade do Estado de Mato Grosso, \\ Alta Floresta, MT, Brasil \\ 2Departamento de Ciências Biológicas, Universidade Estadual do Paraná, \\ União da Vitória, PR, Brasil \\ ${ }^{3}$ Departamento de Ciências Biológicas, Universidade do Estado de Mato Grosso, \\ Nova Xavantina, MT, Brasil \\ ${ }^{4}$ Departamento de Biologia, Nupélia, Universidade Estadual de Maringá, \\ Maringá, PR, Brasil \\ ${ }^{5}$ Departamento de Biotecnologia, Genética e Biologia Celular, \\ Universidade Estadual de Maringá, Maringá, PR, Brasil \\ Corresponding author: L.C. Oliveira \\ E-mail: lucienecastuera@hotmail.com
}

Genet. Mol. Res. 14 (2): 6625-6634 (2015)

Received October 21, 2014

Accepted January 26, 2015

Published June 18, 2015

DOI http://dx.doi.org/10.4238/2015.June.18.5

ABSTRACT. Hypostomus is a group of fish with numerical and structural karyotypic variability. Among them, only six species, three of which belong to the Amazon basin, show a sex chromosome. In this study, we present the karyotype structure of Hypostomus cf. plecostomus from the Teles Pires river basin in the municipality of Alta Floresta, MT. The species has $2 \mathrm{n}=68$ and the karyotype formula $14 \mathrm{~m}+$ $24 \mathrm{sm}+14 \mathrm{st}+16 \mathrm{a}$ [fundamental number $(\mathrm{FN})=120$ ] in males and $15 \mathrm{~m}+$ 
$24 \mathrm{sm}+14 \mathrm{st}+15 \mathrm{a}(\mathrm{FN}=121)$ in females and sex chromosomes $\mathrm{ZZ} / \mathrm{ZW}$. Argyrophilic nucleolar organizer regions (AgNORs) were identified in two pairs of chromosomes at different positions: short arm of the pair 21 and long arm of the pair 27, matching the signals displayed by $18 \mathrm{~S}$ FISH and indicating multiple NORs. Analysis of band C detected few blocks of constitutive heterochromatin in the pericentromeric regions of most chromosomes and the telomeric regions of some pairs, including the nucleolar pair 21. However, large blocks on the long arm of the nucleolar pair 27 still stood out. GC-rich heterochromatin $\left(\mathrm{CMA}_{3}\right)$ was visualized only coincidently with nucleolar sites. Mapping of 5S rDNA sites with FISH revealed markings in eight chromosomes, demonstrating synteny between the $18 \mathrm{~S}$ and $5 \mathrm{~S}$ sites. The data obtained for $H$. cf. plecostomus are important for taxonomic studies of this Amazon complex "H. plecostomus group". The occurrence of sex chromosomes in Amazon species of Hypostomus suggests an evolutionary event that is independent of other species in the group.

Key words: Loricariidae; Cytogenetics; Amazônia Meridional

\section{INTRODUCTION}

Siluriformes fishes comprise the most diverse and widely distributed group in the Neotropical region, with most species found in the Brazilian Amazon. Loricariidae is the family with the largest number of representatives of this order, which is popularly known as plecos or catfish. The genus Hypostomus is considered one of the most taxonomically complex of Neotropical ichthyofauna, which currently comprises 130 valid species (Zawadzki et al., 2014) showing great diversity in the morphology and color pattern and thereby making identification of certain species difficult (Zawadzki et al., 2012).

Early cytogenetic studies in Hypostomus revealed great diversity in number, chromosome morphology and variability in the pattern of distribution of constitutive heterochromatin, characterizing the genus as a group with divergent chromosomal evolution (Artoni and Bertollo, 2001). With the expansion of karyotypic data from this genus, its diversity has been further confirmed by different authors (Alves et al., 2006; Cereali et al., 2008; Rubert et al, 2011; Bueno et al., 2012, 2013). In addition, hypotheses of phylogenetic relationships of the genus Hypostomus, based on taxonomic and molecular analysis (from mitochondrial DNA sequences) allowed some groupings with in this genus (Montoya-Burgos, 2003). However, the phylogeny of this genus is still far from resolved, but the cytogenetic data reported to date for 47 species have prompted discussions on phylogeny and biogeography of Hypostomus (Bueno et al., 2013).

Only $5.9 \%$ of the fish species studied in the Neotropics have been found to have sex chromosomes. Different systems of sex chromosomes found in Neotropical fishes have been recorded involving simples systems such as $\mathrm{XX} / \mathrm{XY}, \mathrm{XX} / \mathrm{X} 0$, and $\mathrm{ZZ} / \mathrm{ZW}$ and multiple systems including $\mathrm{X}_{1} \mathrm{X}_{1} \mathrm{X}_{2} \mathrm{X}_{2} / \mathrm{X}_{1} \mathrm{X}_{2} \mathrm{Y}, \mathrm{XX} / \mathrm{XY}_{1} \mathrm{Y}_{2}, \mathrm{ZZ} / \mathrm{ZW}_{1} \mathrm{~W}_{2}$, and $\mathrm{Z}_{1} \mathrm{Z}_{1} \mathrm{Z}_{2} \mathrm{Z}_{2} / \mathrm{Z}_{1} \mathrm{Z}_{2} \mathrm{~W}_{1} \mathrm{~W}_{2}$ (Oliveira et al., 2009). Among the loricariids, some simple and multiple systems are represented among species of the subfamilies Hypoptopomatinae, Loricariinae and Hypostominae. Specifically in the Hypostomus genus XX/XY system were recorded in Hypostomus ancistroides and $H$. 
macrops (Michele et al., 1977) and ZZ/ZW in Hypostomus sp. G (Artoni et al., 1998, Maurutto, 2010).

The Amazon Basin is well known for its rich fish fauna formed by a variety of water bodies from large rivers to small streams and lakes, which constitute one of the densest water net works in existence (Buckup et al., 2007). The southern Amazon encompasses part of the northern region of the state of Mato Grosso, where is the Teles Pires River, a major river in the Amazon Basin, which supplies the city of Alta Floresta, MT (Ferreira, 1997).

Although Mato Grosso consists of a wide variety of ecosystems, research in the state is concentrated mainly in the region of Cuiabá and the larger rivers that make up the Pantanal. There is also a preference for studies on large fish, primarily for economic purposes such as fish farming and angling, thereby most of the work is carried out in large rivers where most of these species are found. As for the ichthyic fauna of small streams, which are represented mainly by small fish, the data about the wildlife are still scarce (Camargo et al., 2005).

Knowledge of the cytogenetics of the genus Hypostomus in the Amazon Basin is very limited. Additionally, species of this genus are difficult to identify. The Suriname River basin is the type-locality of H. plecostomus (Linnaeus, 1958); however, this species is also cited for low rivers of Guiana (French Guiana, Guiana, and Suriname) (Weber et al., 2012). In the Amazon basin, various forms have been identified as "Group H. plecostomus". They are found in several rivers and encompass large to small individuals with more or less keel-shaped forms identified as $H$. plecostomus, H. cf. plecostomus, $H$. aff. plecostomus, or just Hypostomus sp., demonstrating the complexity of this group.

Given the lack of cytogenetic studies on the species from southern Amazon, and particularly the species H. plecostomus, this study aimed to characterize chromosomes in individuals identified as $H$. cf. plecostomus using classical and molecular cytogenetic methodologies, thus providing new insights to the taxonomy and biogeography of this species.

\section{MATERIAL AND METHODS}

Cytogenetic analysis was performed for 18 specimens ( 4 males and 14 females) of Hypostomus cf. plecostomus collected from the stream Severo (9 $\left.54^{\prime} 30.82^{\prime \prime} \mathrm{S} / 56^{\circ} 03^{\prime} 33.86^{\prime \prime} \mathrm{W}\right)$, a tributary of the Teles Pires River draining into the Amazon Basin region of Alta Floresta in Mato Grosso. The license to fish (No. 31423-1) was obtained from the Ministério do Meio Ambiente (MMA)/Instituto Chico Mendes de Conservação da Biodiversidade (ICMBio)/Sistema de Autorização e Informação em Biodiversidade (SISBIO). Eleven specimens were collected on October 8, 2011, with a body length of 73.09 to $118.0 \mathrm{~mm} \mathrm{SL}$, and they were deposited in the collection of Nupélia (Núcleo de Pesquisas em Ictiologia, Limnologia e Aquicultura), Universidade Estadual de Maringá (UEM), Maringá, PR under the collection number NUP14992.

Chromosome preparations were obtained from kidney cells according to the technique described by Bertollo et al. (1978). The nucleolar organizer regions (Ag-NORs) were detected by impregnation with silver nitrate $\left(\mathrm{AgNO}_{3}\right)$, as described in Howell and Black (1980). AT and $\mathrm{GC}$-specific fluorochromes were obtained by staining with chromomycin $\mathrm{A}_{3}\left(\mathrm{CMA}_{3}\right)$ and 4'-6-diamino-2-phenylindole (DAPI) according to Schweizer (1980). The constitutive heterochromatin was identified by the C-band technique as described in Sumner (1972) and stained with propidium iodide according to the method of Lui et al. (2009). The fluorescent in situ hybridization (FISH) was performed following the protocol described by Pinkel et al. (1986), using 18S rDNA probes from Prochilodus argenteus (Hatanaka and Galetti Jr., 2004) labeled 
with a Biotin Nick Translation Kit and 5S rDNA probes from Leporinus elongatus (Martins and Galetti Jr., 1999) labeled with a Digoxigenin Nick Translation Kit.

The chromosomes were classified according to the arm ratio criteria (RB) proposed by Levan et al. (1964).

\section{RESULTS}

Hypostomus cf. plecostomus showed $2 \mathrm{n}=68$ chromosomes, karyotype formula consisting of $14 \mathrm{~m}+24 \mathrm{sm}+14 \mathrm{st}+16 \mathrm{a}$ and fundamental number $(\mathrm{FN})=120$ for males (Figure $1 \mathrm{~A}$ ), and $15 \mathrm{~m}+24 \mathrm{sm}+14 \mathrm{st}+15 \mathrm{a}$ and $\mathrm{FN}=121$ for females (Figure 1B). The difference between the sexes is due to the presence of an acrocentric pair (33) in males; in females, this pair is represented by a large metacentric and one acrocentric chromosome, featuring the sex chromosome system ZZ/ZW.

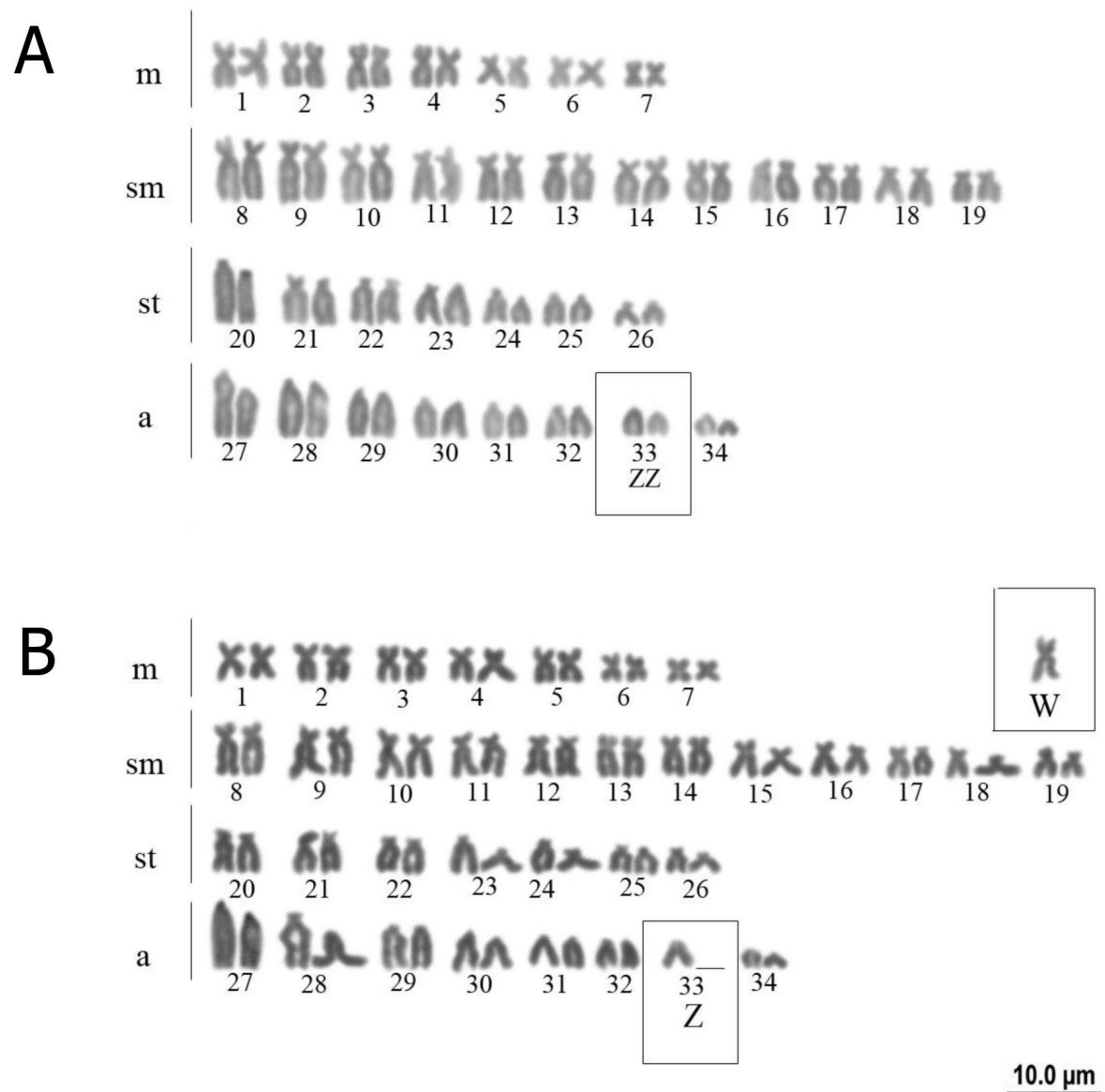

Figure 1. Karyotypes, Giemsa staining, Hypostomus cf. plecostomus. (A) male and (B) female. Featured pair 33, sex chromosome system ZZ/ZW. 
Analysis of band $\mathrm{C}$ showed few and discrete blocks of constitutive heterochromatin in the centromeric regions of most chromosomes and the telomeric position of some chromosomes, especially the long block on the long arm of pair 27 . Heterochromatic blocks were coincident with heteromorphic pairs of NORs (21 and 27) (Figure 2A and B). Sex chromosomes showed no heterochromatic blocks that will differentiate them from other chromosomes.

Hypostomus cf. plecostomus presented a system of multiple NORs identified at the telomeric position on the long arm of pair 27 (a) and the short arm of pair 21 (st); the latter showed an NOR size heteromorphism between homologs (Figure 2A and B). The AgNORs and $\mathrm{CMA}_{3}$ sites were positive (Figure $3 \mathrm{~A}$ ) and negative for DAPI (Figure3B).
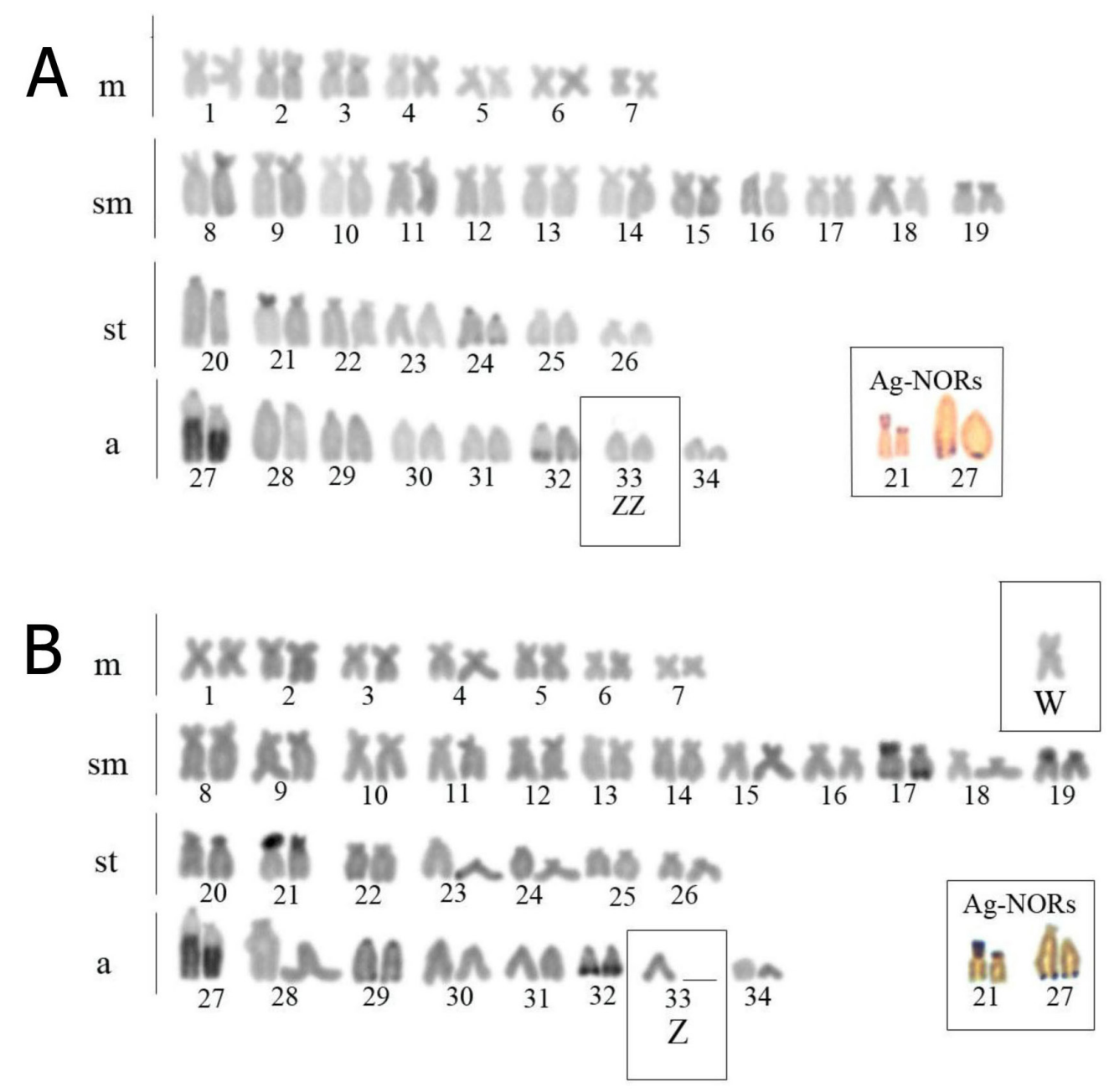

$10.0 \mu \mathrm{m}$

Figure 2. Karyotypes, C banding, Hypostomus cf. plecostomus. (A) and male (B) female. Highlights of sex chromosome system ZZ/ZW, and chromosome positive Ag-NORs, multiple NOR system for both sexes. 
The mapping of the $18 \mathrm{~S}$ rDNA sites by FISH was confirmed through a system involving multiple NOR chromosome pairs 21 and 27, where as the 5S rDNA sites were detected in eight chromosomes. Furthermore, one chromosome (from the pair 27) showed synteny between $18 \mathrm{~S}$ and $5 \mathrm{~S}$ rDNA sites, which were marked at the end portion of the long arm and the short arm, respectively (Figure 3C).

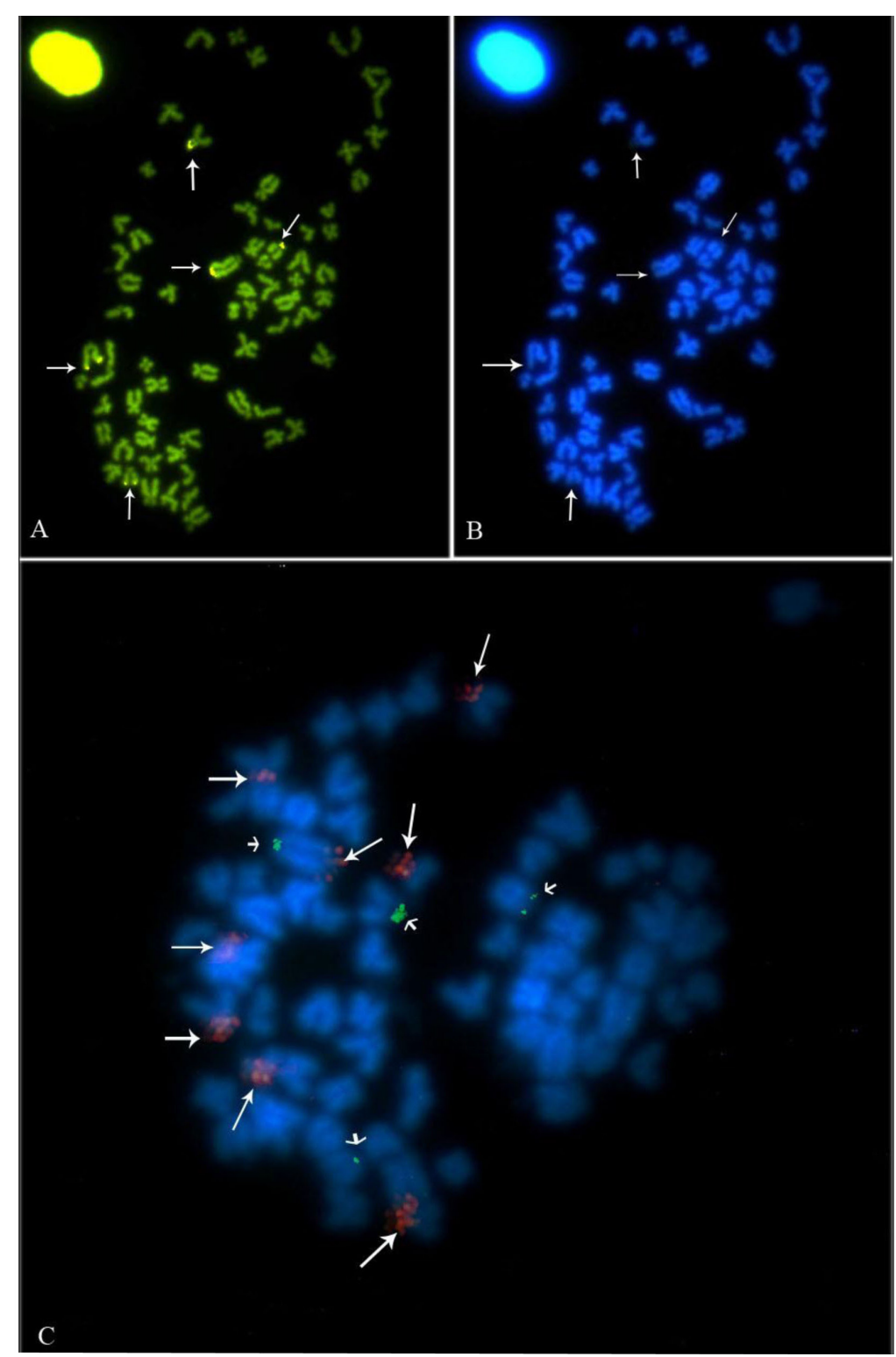

Figure 3. Metaphases Hypostomus cf. plecostomus. (A) Regions highlighted are positive for CMA3; (B) Regions shown are negative for DAPI; and (C) in situ hybridization, small arrows indicate $18 \mathrm{~S}$ and $5 \mathrm{~S}$ regions identified by large arrows. 


\section{DISCUSSION}

Cytogenetic data for Hypostomus plecostomus are scarce; there was only one record of the karyotype with $2 n=54$ chromosomes $(24 m+12 s t+18 a)$, which was described by Muramoto et al. (1968). However, recent data show that chromosome diploid numbers in the genus Hypostomus range from $2 \mathrm{n}=64$ to $2 \mathrm{n}=84$ (Endo et al., 2012; Bueno et al., 2013). The value $2 \mathrm{n}=54$, which was reported for $H$. plecostomus, has been questioned regarding the correct identification of the species (Bueno et al., 2013).

Cytogenetic studies in species of Hypostomus from northern Brazil are still scarce. Thus karyotypes $2 \mathrm{n}=64,65$, and 66 have been recorded for three unidentified species (Hypostomus sp, "Group H. plecostomus") from the Xingu River (PA) (Milhomem et al., 2010) and $2 \mathrm{n}=64$ for $\mathrm{H}$. faveolous from the Araguaia River (Bueno et al., 2013), and $2 \mathrm{n}=72$ for $\mathrm{H}$. goyazensis (Alves et al., 2005). Diploid values $2 \mathrm{n}=68$ detected in $H$. cf. plecostomus (this study) were also recorded in specimens collected from rivers or streams from different states in the Southeast region of Brazil from populations of $H$. ancistroides (Artoni and Bertollo, 1996; Michele et al., 1977; Alves et al., 2006; Endo et al., 2012; Bueno et al., 2013), H. macrops (Michele et al., 1977) and Hypostomus sp (Martinez et al., 2011), among others. Based on molecular data, Montoya-Burgos (2003) recognized four monophyletic groups within Hypostomus, among which his D2 group includes species of $H$. affinis, $H$. ancistroides, $H$. boulengeri, $H$. commersoni, $H$. punctatus, and $H$. watwata. Among these species, $2 \mathrm{n}=66$ was reported for $H$. affinis and $2 \mathrm{n}=68$ for $H$. ancistroides, H. commersoni, and H. plecostomus. Therefore, the diploid number of $2 \mathrm{n}=66$ to $2 \mathrm{n}=68$ is a base number for this group.

Artoni and Bertollo (2001) suggested that $2 \mathrm{n}=54$ chromosomes is plesiomorphic for loricariids. The diploid number in Hypostomus was reported to vary between $2 \mathrm{n}=54$ chromosomes in H. plecostomus (Muramoto et al., 1968) and $2 \mathrm{n}=84$ chromosomes in Hypostomus sp. 2 (Cereali et al., 2008). However, Artoni and Bertollo (2001) considered that the species with high diploid number are probably more derived than those with $2 \mathrm{n}=54$ and that high diploid number was the result of chromosomal rearrangements as centric fissions. Moreover, these authors suggested that there is an inverse relationship between the number and the FN, i.e. species with higher diploid numbers have higher number of subtelocentric/acrocentric chromosomes. Given this proposition, data from the present study for $H$. cf. plecostomus demonstrate the number intermediate between metacentric/submetacentric and subtelocentric/acrocentric chromosomes.

Sex chromosomes in the genus Hypostomus are relatively rare and the occurrence of systems with $\mathrm{XX} / \mathrm{XY}$ in $H$. ancistroides and H. macrops (= Plecostomus ancistroides and P. macrops, respectively) (Michele et al., 1977) and Hypostomus soniae (Oliveira, 2013) and ZZ/ZW systems in Hypostomus sp. G (Artoni et al.,1998), H. albopunctatus (Maurutto, 2010), and H. cf. plecostomus suggest that the presence of sex chromosomes is a derived characteristic of this group.

The analysis of band C in Hypostomus sp G (Artoni et al., 1998) and H. albopunctatus (Maurutto, 2010) revealed that $\mathrm{Z}$ chromosome is differentiated from its complement by a heterochromatic interstitial band. Moreover, a heterochromatic band along almost entire length of chromosome $\mathrm{W}$ was observed only in $H$. albopunctatus. In most species of Neotropical fishes with sex chromosomes, addition and/or deletion of heterochromatin or chromosomal rearrangements such as pericentric inversions or Robertsonian translocations involving one of the homologous chromosomes have been suggested important mechanisms in the origin of simple sex chromosome systems (Almeida-Toledo et al., 2000). Multiple sex chromosome systems are those where chromosomal rearrangements are cited as the fundamental mechanisms in the 
origin of the complex systems (Oliveira et al., 2007). In the case of $H$. cf. plecostomus, whose sex chromosomes ZZ/ZW showed no differentiation of the $\mathrm{C}$ band, the species probably originated from chromosomal rearrangements such as inversions and/or translocations, suggesting independent events in karyotypic diversification of the genus. The standard $\mathrm{C}$ band observed in $H$. cf. plecostomus with a few conspicuous blocks on the long arm of the chromosome as well as on the short arms of other chromosomes, was also found in other species of the genus, such as H. affinis (Kavalco et al., 2004), H. nigromaculatus (Rubert et al., 2008), and H. cochliodon (Cereali et al., 2008). This corroborates the results of Artoni and Bertollo (1996) and Kavalco et al. (2004), who reported that Hypostomus has relatively little constitutive heterochromatin. However, large blocks of heterochromatin have been observed in the terminal region of some chromosomes in this genus. The $\mathrm{C}$-band heteromorphism has also been reported for the genus, and in $H$. cf. plecostomus, the observed heteromorphism in pair 27 (the largest acrocentric complement) was due to differences in the size of the heterochromatic block in the terminal region of the long arm, possibly as a result of amplification of the heterochromatin.

Single NOR is considered a basal characteristic in the family Loricariidae (Alves et al., 2006); however, Hypostomus shows variability in the number and position of NORs (Artoni and Bertollo, 2001), with the system of multiple NORs at the terminal position, as found in the present study, being the most common characteristic. The AgNOR sites detected on the short arm and long arm pair 21 were coincident with the pair 27 FISH18S, with heterochromatic GC-rich blocks $\left(\mathrm{CMA}_{3}+\right)$ content.

In Hypostomus, data on the physical location of $5 \mathrm{~S}$ rDNA sites are still scarce, but variations in the number and position of these markings have been reported (Traldi et al., 2012). H. iheringii was found to have only one pair of chromosomes marked by FISH 5S (Traldi et al., 2012), H. regani had nine sites identified (Mendes-Neto et al., 2011), and $H$. affinis (Kavalco et al., 2005) and H. cf. plecostomus had eight chromosomes carrying 5S rDNA. Moreover, synteny has been observed between the $18 \mathrm{~S}$ and 5S rDNAs in fish species belonging to the basal groups of Loricariidae, which was considered a primitive state within the family (Ziemniczak et al., 2012). For $H$. cf. plecostomus, the synteny was observed in only one of the homologs of the pair 27. The absence of fluorescent signals for the 5S rDNA probe on the homolog pair 27 may be related to their diminutive size, being imperceptible by the technique, or deletion, which was not detrimental to the species.

The data obtained for $\mathrm{H}$. cf. plecostomus are an important chromosomal characterization providing information for future taxonomic studies of this complex " $H$. plecostomus group". The occurrence of a sex chromosome system in this species is a given reference for comparative and evolutionary studies in this group. Moreover, the presence of sex chromosome system in six species of Hypostomus, three collected in the Amazon basin (Hypostomus sp. G, $H$. cf. plecostomus, and $H$. soniae), suggests that the distribution of sex systems is an independent evolutionary event in relation to other species of the genus. However, proper understanding of the history of the karyotype evolution of Hypostomus requires more detailed cytogenetic studies in Amazonian species.

\section{ACKNOWLEDGMENTS}

Research supported by Coordenadoria de Aperfeiçoamento de Pessoal de Nível Superior (CAPES), Fundação de Amparo à Pesquisa do Estado Mato Grosso (FAPEMAT), and Conselho Nacional de Desenvolvimento Científico e Tecnológico (CNPq). 


\section{REFERENCES}

Almeida-Toledo LF, Foresti F and Toledo-Filho SA (2000). Karyotypic evolution in Neotropical fresh water fish. In: Chromosomes today Vol. 13 (Olmo E and Redi CA eds.) Birkhäuser Verlag, Basel, 169-182.

Alves AL, Oliveira C and Foresti F (2005). Comparative cytogenetic analysis of eleven species of subfamilies Neoplecostominae and Hypostominae (Siluriformes, Loricariidae). Genetica 124: 127-136.

Alves AL, Oliveira C, Nirchio M, Granado A et al. (2006). Karyotypic relationship among the tribes of Hypostominae (Siluriformes: Loricariidae) with description of XO sex chromosome system in a Neotropical fish species. Genetica 128: $1-9$.

Artoni RF and Bertollo LAC (1996). Cytogenetic studies on Hypostominae (Pisces, Siluriformes, Loricariidae). Considerations on karyotype evolution in the genus Hypostomus. Caryologia 49: 81-90.

Artoni RF and Bertollo LAC (2001). Trends in the karyotype evolution of Loricariidae fish (Siluriformes). Hereditas 134: 201-210.

Artoni RF, Venere PC and Bertollo LAC (1998). A heteromorphic ZZ/ZW sex chromosome system in fish, genus Hypostomus (Loricariidae). Cytologia 63: 421-425.

Bertollo LAC, Takahashi CS and Moreira-Filho O (1978). Cytotaxonomic considerations on Hoplias lacerdae (Pisces, Erythrinidae). Rev. Bras. Genet. 1: 103-120.

Buckup PA, Menezes NA and Ghazzi MS (eds.) (2007). Catálogo das espécies de peixes de água doce do Brasil. Museu Nacional, Rio Janeiro.

Bueno V, Zawadzki CH and Margarido VP (2012). Trends in chromosome evolution in the genus Hypostomus Lacépède, 1803 (Osteichthys, Loricariidae): a new perspective about the correlation between diploid number and chromosome types. Rev. Fish Biol. Fish. 22: 241-250

Bueno V, Venere PC, Zawadzki CH and Margarido VP (2013). Karyotypic diversification in Hypostomus Lacépède, 1803 (Siluriformes, Loricariidae): biogeographical and phylogenetic perspectives. Rev. Fish Biol. Fish. .23: 103-112.

Camargo M, Giarnizzo T and Carvalho Jr. J (2005). Levantamento ecológico rápido da fauna ictica de tributários do médio-baixo Tapajós e Curua. Bol. Mus. Para. Emilio Goeldi 2: 229-247.

Cereali SS, Pomini E, Rosa R, Zawadzki CH et al. (2008). Karyotype description of two species of Hypostomus (Siluriformes, Loricariidae) of de Planalto da Bodoquena, Brazil. Genet. Mol. Res.7: 583-591.

Endo KS, Martinez ERM, Zawadzki CH, Paiva LRS et al. (2012). Karyotype description of possible new species of the Hypostomus ancistroides complex (Teleostei: Loricariidae) and other Hypostominae. Acta Sci. Biol. Sci. 34: 181-189.

Ferreira JC (1997). Mato Grosso e seus municípios. Secretaria de Estado de Educação Cuiabá.

Hatanaka T and Galetti Jr. PM (2004). Mapping of the 18S and 5S ribosomal RNA genes in the fish Prochilodus argenteus Agassiz, 1829 (Characiformes, Prochilodontidae). Genetica 122: 239-244.

Howell WM and Black DA (1980). Controlled silver-staining of nucleolus organizer regions with a protective colloidal developer: a 1-step method. Experientia 36: 1014-1015.

Kavalco KF, Pazza R, Bertollo LAC and Moreira-Filho O (2004). Heterochromatin characterization of four fish species of the family Loricariidae (Siluriformes). Hereditas 141: 237-242.

Kavalco KF, Pazza R, Bertollo LAC and Moreira-Filho O (2005). Karyotypic diversity and evolution of Loricariidae (Pisces, Siluriformes). Heredity 94: 180-186.

Levan A, Fredga K and Sandberg AA (1964). Nomenclature for centromeric position on chromosomes. Hereditas 52: 201-220.

Linnaeus C (1758). Systema naturae sive regna tria naturae, secundum classes, ordines, genera, species, cum characteribus, differentiis, synonymis, locis. Tomus I. Editio decima, reformata, Laurentius Slavius: Holmiae.

Lui RL, Blanco DR, Margarido VP and Moreira-Filho O (2009). First description of B chromosomes in the family Auchenipteridae Parauchenipterus galeatus (Siluriformes) of the São Francisco River basin (MG, Brazil). Micron 40: $552-559$.

Martinez ERM, Zawadzki CH, Foresti F and Oliveira C (2011). Cytogenetic analysis of five Hypostomus species (Siluriformes, Loricariidae). Genet. Mol. Biol. 34: 562-568.

Martins C and Galetti PM Jr (1999). Chromosomal localization of 5S rDNA genes in Leporinus fish (Anostomidae, Characiformes). Chromosome Res. 7: 363-367.

Maurutto FAM (2010). Contribuição à citogenética de peixes do gênero Hypostomus Lacépède (1803) (Teleostei, Loricariidae). Master's Thesis, UFPR, Curitiba.

Mendes-Neto EO, Vicari MR, Artoni RF and Moreira-Filho O (2011). Description of karyotype in Hypostomus regani (Ihering, 1905) (Teleostei, Loricariidae) from the Piumhi river in Brazil with comments on karyotype variation found in Hypostomus. Comp.Cytogenet. 5: 133-142. 
Michele JL, Takahashi CS and Ferrari I (1977). Karyotypic study of some species of the family Loricariidae (Pisces). Cytologia 42: 539-546.

Milhomem SSR, Castro RR, Nagamachi CY, Souza CAP et al. (2010). Different cytotypes in fishes of the genus Hypostomus Lacépède, 1803, (Siluriformes: Loricariidae) from Xingu river (Amazon region, Brazil). Comp.Cytogenet. 4: 45-54.

Montoya-Burgos JI (2003). Historical biogeography of the catfish genus Hypostomus (Siluriformes: Loricariidae), with implications on the diversification of Neotropical ichthyofauna. Mol. Ecol. 12: 1855-1867.

Muramoto JI, Ohno S and Atkin NB (1968). On the diploid state of the fish order Ostariophysi. Chromosoma 24: 59-66.

Oliveira LC (2013). Caracterização citogenética de espécies de peixes da Amazônia meridional: uma contribuição à estimativa da biodiversidade da região de Alta Floresta - MT. Master'sthesis, UEM, Maringá.

Oliveira RR, Feldberg E, Anjos MB and Zuanon J (2007). Karyotype characterization and ZZ/ZW sex chromosome heteromorphism in two species of the catfish genus Ancistrus Kner, 1854 (Siluriformes: Loricariidae) from the Amazon basin. Neotrop. Ichthyol. 5: 301-306.

Oliveira C, Foresti F and Hilsdorf AWS (2009). Genetics of neotropical fish: from chromosomes to populations. Fish Physiol. Biochem. 35: 81-100.

Pinkel D, Straume T and Gray JW (1986). Cytogenetic analysis using quantitative, high sensitivity, fluorescence hybridization. Proc. Natl. Acad. Sci. U S A 83: 2934-2938.

Rubert M, Zawadzki HC and Giuliano-Caetano L (2008). Cytogenetic characterization of Hypostomus nigromaculatus (Siluriformes: Loricariidae). Neotrop. Ichthyol. 6: 93-100.

Rubert M, Rosa R, Jerep FC, Bertollo LAC et al. (2011). Cytogenetic characterization of four species of the genus Hypostomus Lacépède, 1803 (Siluriformes, Loricariidae) with comments on its chromosomal diversity. Comp. Cytogen. 5: 397-410.

Schweizer D (1980). Simultaneous fluorescent staining of Rbands and specific heterochromatic regions (DA-DAPI bands) in human chromosomes. Cytogenet. Cell Genet. 27: 190-193.

Sumner AT (1972). A simple technique for demonstrating centromeric heterochromatin. Exp. Cell Res. 75: 304-306.

Traldi JB, Vicari MR, Blanco DR, Martinez JF, et al. (2012). First karyotype description of Hypostomus iheringii (Regan, 1908): a case of heterochromatic polymorphism. Comp. Cytogenet. 6: 115-125.

Weber C, Covain R and Fisch-Muller S (2012). Identity of Hypostomus plecostomus (Linnaeus, 1758), with an overview of Hypostomus species from the Guianas (Teleostei: Siluriformes: Loricariidae). Cybium 36: 195-227.

Zawadzki CH, Birindelli JLO and Lima FCT (2012). A new armored catfish species of the genus Hypostomus Lacépède, 1803 (Siluriformes: Loricariidae) from the upper rio Xingu basin, Brazil. Neotrop. Ichthyol. 10: 245-253.

Zawadzki CH, Tencatt LFC and Froehlich O (2014). A new unicuspid-toothed species of Hypostomus Lacépède, 1803 (Siluriformes: Loricariidae) from the rio Paraguai basin. Neotrop. Ichthyol. 12: 97-104.

Ziemniczak K, Barros AV, Rosa KO, Nogaroto V, et al. (2012). Comparative cytogenetics of Loricariidae (Actinopterygii: Siluriformes): emphasis in Neoplecostominae and Hypoptopomatinae. Ital. J. Zool. 79: 492-501. 